\title{
DAMPAK PEMBERIAN TEPUNG BAWAH PUTIH TERHADAP PROFIL LIPID LIVER DAN PLASMA DARAH PUYUH YANG MENGALAMI CEKAMAN PANAS
}

\section{The effect of Garlic Powder in Ration on Liver and Blood Plasma Lipid Profile in Heat-stressed Quail}

Eli Sahara, Sofia Sandi, Meisji Liana Sari

Program Studi Peternakan, Fakultas Pertanian, Universitas Sriwijaya

Jl. Raya Palembang-Prabumulih KM.32, Indralaya, Ogan Ilir, 30662

Sumatera Selatan, Indonesia

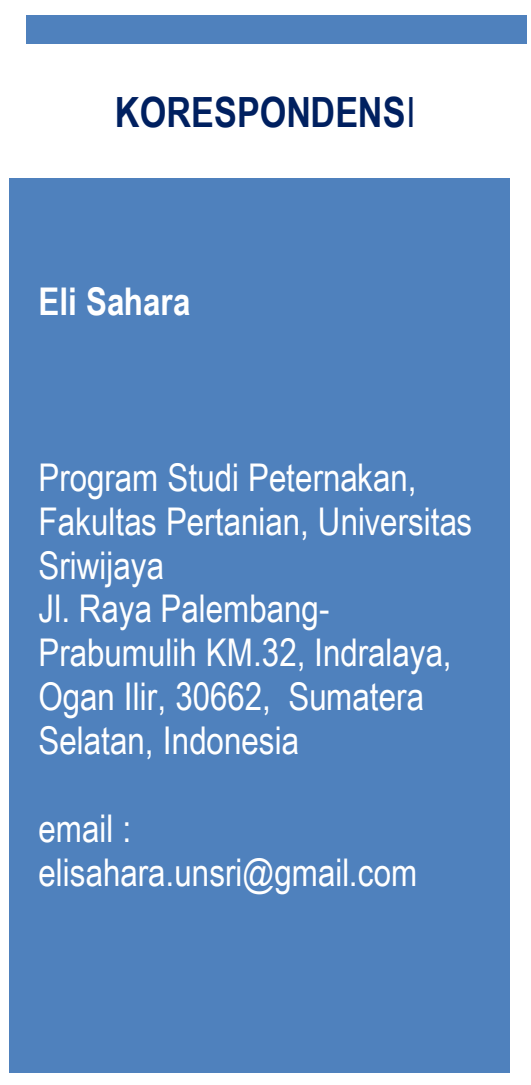

\begin{abstract}
ABSTRAK
Temperatur yang tinggi penyebabkan penurunan fungsi fisiologis dan metabolisme nutrien, sehingga berdampak terhadap penurunan produksi dan pengaturan panas tubuh. Penambahan bahan alamiah seperti tepung bawang putih merupakan salah satu teknik untuk menanggulangi dampak buruk stres panas tersebut. Dua ratus ekor puyuh berjenis kelamin betina, dengan rata-rata berat badan $124,52 \pm 4,13 \mathrm{~g}$, berumur 12 minggu, telah digunakaan dalam percobaan ini, untuk mengkaji dampak penambahan tepung bawang putih dalam ransum terhadap profil lipid liver dan plasma darah puyuh. Sampel ternak puyuh dibagi kedalam empat group perlakuan, masing-masing 50 ekor. Perlakuan percobaan, terdiri dari kelompok puyuh dengan penambahan tepung bawang putih masingmasing 5, 30, 55 dan $80 \mathrm{~g} / \mathrm{kg}$ ransum. Berdasarkan hasil penelitian menunjukkan pemberian tepung bawang putih mampu menurunkan profil lipid tapi tetap meningkatkan HDL meskipun dalam keadaan stress panas. Tepung bawang putih memiliki peran penting dalam mencegah perubahan metabolisme lipid secara
\end{abstract} berlebihan, sehingga secara keseluruhan mampu menurunkan lipid, tapi transportasi lipid ke liver tetap dipertahankan melalui peran HDL.

Kata Kunci: garlic; stres panas; lipid; puyuh 


\section{ABSTRACT}

The temperatur plays an important role for reducing fisiologic function, nutrient metabolism, and its influence on the performance and economic loss. Supplemented of garlic powder is one the efforts to avoid the negative impact of heat stress. Two hundred of female quails, 12 weeks of age, were used ini this study to investigate the impact of garlic powder on liver and blood plasma lipid profile in heat-stressed quail. Animal sample were obtained at 12 wh of age ramdomly assigned to four groups of treatment. Each group of treatment involved 5 replicates with 10 quails each (50 laying quails per group). All of the groups were provided

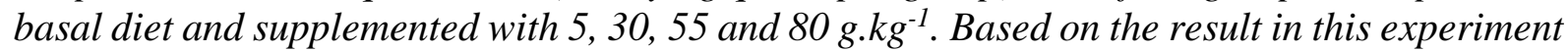
showed that heat stress contibutes of the reduces of lipid profile in liver and blood plasma. In conclusion, chemical compound in garlic owder plays the main role for reducing lipid but can be maintained the lipid transportation to liver by HDL.

Keywords: garlic; heat stress; lipid; quail

\section{PENDAHULUAN}

Perkembangan dan budidaya burung puyuh di seluruh wilayah Indonesia, terus mengalami perkembangan. Meskipun demikian faktor lingkungan terutama temperatur menjadi salah satu faktor penghambat dalam perkembangannya. Sebagai hewan homoeterm, penyesuaian panas atau dissipasi panas lingkungan dan tubuhnya menjadi sangat penting untuk mempertahankan kehidupannya.

Temperatur lingkungan yang terus meningkat menjadi permasalahan penting bagi pengembangan dan pertumbuhan puyuh. Zona pemeliharaan dengan temperatur lingkungan di atas zona nyamannya menyebabkan dampak buruk. Dampak ini terutama terhadap proses fisiologik dan biokimiawinya, yang diarahkan untuk melakukan homeostasis (Mushawwir dan Latipudin, 2011; Howard et al., 2013). Homeostasis meningkat untuk mencapai derajat keseimbangan fungsi organ dan laju metabolisme (Latipudin dan Mushawwir, 2011), dalam rangka pengaturun panas tubuh (thermoregulasi). Proses ini berdampak terhadap pergeseran fungsi energi, dari tujuan produksi menjadi energi untuk memenuhi pencapaian homeostasis. Semakin lama paparan cekaman panas ini, maka intake pakan menurun (Al-Haidary et al., 2001) sehingga kecukupan energi menjadi berkurang (Mushawwir, 2015).

Sisi lain, cekaman panas juga meningkatkan resiko mutasi DNA dan denaturasi protein tubuh (enzim, reseptor, transporter sel, hormon). Mutasi DNA dan denaturasi protein dipicu oleh meningkatnya produksi radikal bebas (Shinder et al., 2007; Tao et al., 2013; Slimen et al., 2016; Mushawwir dkk., 2019) melalui proses oksidasi reduksi mitokondria (stress sellular), dan atau cekaman langsung dalam bentuk radiasi panas lingkungan ke tubuh ternak puyuh. Kondisi tersebut berdampak luas terhadap metabolisme, khususnya produksi energi di bagian matriks dalam mitokondria. Begitu pula terhadap metabolisme lipid sebagai dampak radikal bebas hingga menyebabkan kematian embryo (Sadiah dan Mushawwir, 2015).

Strategi yang dapat diterapkan untuk mengurangi dampak cekaman panas ini, adalah pemberian feed aditif yang alami, yang terkandung dalam tepung bawang putih (garlik). Bawang putih mengandung minyak atsiri, serta diallyl (Dn-S) yang merupakan komponen atsiri yang memiliki atom oksigen (O) dan sulfur (S) yang reaktif untuk dapat berikatan dengan radikal bebas (Mushawwir dkk., 2011; Lee et al., 2014). Diharapkan dengan kemampuan reaksinya, mampu mencegah dampak buruk radikal bebas dalam 
menurunkan laju metabolism, khususnya lipid.

Oleh karena itu, kajian terhadap dampak pemberian tepung bawang putih penting dilakukan terkait dengan laju metabolism lipid dalam liver dan plasma darah selama berlangsungnya cekaman panas.

\section{METODE PENELITIAN}

\section{Ternak Percobaan dan Ransum}

Dua ratus (200) ekor puyuh berjenis kelamin betina, dengan rata-rata berat badan $124,52 \pm 4,13 \mathrm{~g}$, berumur 12 minggu, telah digunakaan dalam percobaan ini. Sampel ternak puyuh dibagi kedalam empat kelompok perlakuan, masing-masing terdiri dari 50 ekor. Tiap-tiap perlakuan terdiri dari lima kali ulangan, sehingga setiap ulangan terdiri dari 10 ekor sampel puyuh.

Sampel puyuh percobaan ditempatkan di dalam kandang koloni satu tingkat yang disekat berdasarkan unit percobaan. Kandang percobaan dibuat dari kombinasi kayu balok dan kawat rang. Kandang percobaan yang digunakan sebanyak 4 unit. Keempat kandang dilengkapi dengan lampu pijar sebagai sumber panas serta thermostat, dengan kisaran temperatur kandang $36-38^{\circ} \mathrm{C}$ atau rata-rata $37^{\circ} \mathrm{C}$. Perlakuan panas diberikan pada pukul 06.00 pagi hari sampai dengan 09.00 malam hari.

Ransum puyuh percobaan selama penelitian diberikan secara ad-libitum. Ransum yang diberikan adalah ransum komersial yang diperoleh dari poultry shop. Komposisi energi metabolisme dan nutrien ransum ditampilkan pada Tabel 1 .

Tabel 1. Kandungan Energi Metabolis dan Zat Makanan Ransum Penelitian Puyuh

\begin{tabular}{lc}
\hline Energi Metablisme dan Nutrien & Ransum Penelitian \\
\hline Energi Metabolisme (Kkal/kg) & 2703,74 \\
Protein Kasar (\%) & 19,89 \\
Kalsium (\%) & 1,63 \\
Phospor (\%) & 1,14 \\
Lisin (\%) & 1,54 \\
Metionin (\%) & 1,02 \\
Serat Kasar (\%) & 3,37 \\
Lemak Kasar $(\%)$ & 6,74 \\
\hline
\end{tabular}

\section{Pembuatan Tepung Bawang Putih}

Sampel bawang putih diiris halus, kemudian dijemur dengan sinar matahari lansung hingga diperoleh kadar air kira-kira $15 \%$. Bawang putih yang telah kering kemudian digiling halus.

Sebelum digunakan, tepung bawang ptuih terlebih dahulu diovenkan selama dua jam dengan temperatur $40^{\circ} \mathrm{C}$. Penambahan tepung bawang putih kedalam ransum sebanyak sesuai perlakuan, dilakukan setiap kali hari di pagi hari sebelum pemberian pakan kepada puyuh-puyuh percobaan.

\section{Koleksi dan Analisis Sampel}

Percobaan ini telah dilakukan selama tiga bulan di Peternakan Puyuh Jaya Mandiri, Cikole Sukabumi. Pengambilan sampel darah pada tiap-tiap puyuh percobaan telah dilakukan pada umur 16, 20 dan 24 minggu. Sampel darah dikoleksi dari vena jugularis sebanyak $3 \mathrm{~mL}$ dari tiap-tiap puyuh, menggunakan spoit dengan ukuran jarum 22. Sampel darah ditampung ke dalam tabung venojette $3 \mathrm{~mL}$ yang mengandung EDTA. Tabung venojette yang berisi sampel darah ditampatkan di 
dalam cool box yang berisi es gel sebagai pendingin.

Tabung venojette selanjutnya di centrifuge di Laboratorium Fisiologivdan Biokimia, Fakultas Peternakan Universitas Padjadjaran, untuk memisahkan plasma ekor.

Analisis sampel profil lipid plasma dan jaringan telah dilakukan dengan menggunakan teknik spektrofotometer. Standar dan reagent yang digunakan, metode reaksi dan jumlah sampel serta pereaksinya mengikuti petunjuk dalam prosedur kit berdasar Biolabo KIT, France dan Mybiosource KIT, MyBiosource Inc. USA.

\section{Aplikasi Percobaan dan Analisis Data}

Penelitian dilakukan dengan lima jenis perlakuan percobaan, sebagai berikut: $\mathrm{A}$ : Pemberian tepung bawang putih $5 \mathrm{~g} / \mathrm{kg}$ ransum

B : Pemberian tepung bawang putih 30 $\mathrm{g} / \mathrm{kg}$ ransum

C : Pemberian tepung bawang putih 55 $\mathrm{g} / \mathrm{kg}$ ransum

$\mathrm{D}$ : Pemberian tepung bawang putih $80 \mathrm{~g} / \mathrm{kg}$ ransum

Pemberian ransum yange
mengandung tepung bawang putih dilakukan setiap pagi sebelum diberi air koefisien kontras $\left(\mathrm{TC}_{\mathrm{i}}\right)=0$

\section{HASIL DAN PEMBAHASAN}

Pengaruh pemberian tepung bawang putih terhadap ternak puyuh yang mengalami cekaman panas, berdasarkan hasil penelitian ditampilkan pada Tabel 2.

Selama percobaan ini berlangsung, kelompok-kelompok percobaan puyuh ditempatkan dalam kandang dengan temperatur diatas zona nyaman puyuh atau uppet themoneutral zone. Aktivitas darahnya. Plasma darah yang telah diperoleh dimasukkan ke dalam tabung sampel untuk dianalisis profil lipidnya. Pengambilan jaringan hati dilakukan pada akhir penelitian. Setip ulangan telah diambil sampel jaringan hatinya sebayak dua

minum. Data yang diperoleh dianalisis dengan menggunakan metode ortogonal polinomial.Suatu derajat polynomial ke-n digunakan untuk mengetahui hubungan antara peubah respon $\mathrm{Y}$ dan peubah predictor $\mathrm{X}$ diujikan sebagai berikut $: \mathrm{Y}=\alpha$ $+\beta_{1} X+\beta_{2} X^{2}+\ldots .+\beta_{n} X^{n}$

Perhitungan untuk mendapatkan koefisien orthogonal polynomial untuk derajat polynomial pertama (linier), derajat polynomial kedua (kuadratik) dan derajat polynomial ketiga (kubik), sebagai berikut :

$$
\begin{aligned}
& \mathrm{L}=\mathrm{a}+\mathrm{X}_{1} \\
& \mathrm{Q}_{1}=\mathrm{b}+\mathrm{cX} \mathrm{X}_{1}+\mathrm{X}_{\mathrm{i}}^{2} \\
& \mathrm{C}_{1}=\mathrm{d}+\mathrm{e} \mathrm{X}_{1}+\mathrm{f}_{1}^{2}+\mathrm{X}_{1}^{2}
\end{aligned}
$$

Analisis dilanjutkan dengan menggunakan uji kontras orthogonal, kontras ber-db tunggal sebagai fungsi linear (L) dari jumlah-jumlah perlakuan:

$$
\begin{aligned}
& \mathrm{L}=\mathrm{TC}_{\mathrm{i}} \mathrm{J}_{\mathrm{i}} \\
& \quad=\mathrm{C}_{1} \mathrm{~J}_{1}+\mathrm{C}_{2} \mathrm{~J}_{2}+\ldots+\mathrm{C}_{\mathrm{t}} \mathrm{J}_{\mathrm{t}} \\
& \text { Dimana: } \\
& \mathrm{C}_{\mathrm{i}}=\text { koefisien kontras ke- } \mathrm{i} \\
& \mathrm{J}_{\mathrm{i}}=\text { jumlah nilai pengamatan ke-i } \\
& \mathrm{t}=\text { banyaknya perlakuan jumlah } \\
& \mathrm{r}=\text { jumlah lokal kontrol/ulangan }
\end{aligned}
$$

perombakan atau katabolisme lipid, cenderung tetap mengalami peningkatan seiring dengan penambahan level tepung bawang putih dalam ransum.

Berdasarakan hasil percobaan menunjukkan bahwa kadar lipid mengalami penurunan sejalan dengan penambahan tepung bawang putih, baik dalam liver maupun dalam plasma darah. 
Tabel 2. Profil Lipid Liver dan Plasma Darah Puyuh yang Mengalami Cekaman Panas

\begin{tabular}{lrrrr}
\hline \multirow{2}{*}{ Parameter } & \multicolumn{3}{c}{ Perlakuan Tepung Bawang Putih (TPB) } \\
\cline { 2 - 5 } & $\begin{array}{c}\mathrm{TBP} \\
5 \mathrm{~g} / \mathrm{kg}\end{array}$ & $\begin{array}{c}\mathrm{TBP} \\
30 \mathrm{~g} / \mathrm{kg}\end{array}$ & $\begin{array}{c}\mathrm{TBP} \\
55 \mathrm{~g} / \mathrm{kg}\end{array}$ & $\begin{array}{c}\mathrm{TBP} \\
80 \mathrm{~g} / \mathrm{kg}\end{array}$ \\
\hline & & & & \\
A. Liver & $25,95^{\mathrm{a}}$ & $23,52^{\mathrm{ab}}$ & $23,23^{\mathrm{b}}$ & $21,52^{\mathrm{c}}$ \\
1. Lemak (\%) & $361,69^{\mathrm{a}}$ & $358,63^{\mathrm{a}}$ & $325,73^{\mathrm{b}}$ & $316,27^{\mathrm{c}}$ \\
2. Trigliserida (mg/dg) & $184,47^{\mathrm{a}}$ & $178,63^{\mathrm{a}}$ & $146,84^{\mathrm{b}}$ & $116,92^{\mathrm{c}}$ \\
3. Kolesterol Total (mg/dg) & & & & \\
B. Plama Darah & & & & \\
1. Trigliserida (mg/dl) & $837,64^{\mathrm{a}}$ & $824,62^{\mathrm{b}}$ & $811,63^{\mathrm{b}}$ & $783,86^{\mathrm{c}}$ \\
2. Kolesterol Total (mg/dL) & $318,72^{\mathrm{a}}$ & $326,52^{\mathrm{b}}$ & $311,72^{\mathrm{c}}$ & $284,72^{\mathrm{d}}$ \\
3. LDL (mg/dL) & $12,54^{\mathrm{a}}$ & $12,62^{\mathrm{b}}$ & $11,62^{\mathrm{b}}$ & $9,72^{\mathrm{c}}$ \\
4. HDL (mg/dl) & $56,78^{\mathrm{a}}$ & $56,84^{\mathrm{b}}$ & $74,36^{\mathrm{c}}$ & $69,13^{\mathrm{d}}$ \\
\hline
\end{tabular}

Rata-rata yang diikuti notasi abjad yanag berbeda pada baris yang sama menunjukkan perbedaan yang nyata $(\mathrm{P}<0,05) ; \mathrm{Dn}-\mathrm{S}=$ Diallyl $\mathrm{n}-\mathrm{Sulfida}$

Rendahnya kadar kolesterol darah disebabkan senyawa aktif bawang putih yang dapat menurunkan sintesis kolesterol endogen dalam hati yaitu allicin. Seperti yang diteliti oleh Yalcin et. al. (2007), disulphideoxide tidak jenuh (allicin) menghambat enzim hepatic 3-hydroxy-3-methylglutarylCoA (HMG-CoA) reductase serta enzim cholesterol 7 $\alpha$-hydroxylase dalam proses biosintesis kolesterol (Mushawwir dan Latipudin, 2013; Ma et al., 2014). Selanjutnya Kim et al. (2009); Loyou et al. (2014) dan Mushawwir et al. (2018) menyatakan bahwa Allicin dapat menurunkan nicotinanmide adenine dinucleotide hidrogenase (NADH) dan nicotinamide adenine dinucleotide phosphate hidrogenase (NADPH) dengan mengikat SH group (bagian fungsional) dari Ko-A sehingga pembentukan kolesterol di hati berkurang.

Disamping hal tersebut, saponin yang terdapat di bawang putih juga dapat menurunkan kolesterol eksogen dalam sintesis kolesterol. Olobbatoke et al. (2011) dan Pearce et al. (2013) melaporkan bahwa diosgenin (saponin steroid) merupakan senyawa yang sangat bermanfaat untuk mengontrol hiperkolesterolemia dengan menghambat absorpsi kolesterol dan meningkatkan ekskresi kolesterol dalam feses. Lebih spesifik saponin bekerja secara luminal tetapi tidak melibatkan reaksi kompleks kimia dengan kolesterol (Oresanya et al., 2008; Chio et al., 2010; Mushawwir dan Latipudin, 2012; ).

Kadar trigliserida yang tinggi saat fase produksi diperlukan untuk pembentukan kuning telur, dimana asam-asam lemak yang beasal dari trigliserida sangat diperlukan sebagai prekursor pembentukan kuning telur. Trigliserida diperoleh dari hasil hidrolisis enzimatis lipid pada saluran pencernaan. Selanjutnya dimanfaatkan oleh sel hati dan sisanya disintesis kembali dan disimpan dalam bentuk badan lemak atau jaringan lemak sebagai energi simpanan (Chauhan et $a l$. , 2014). Namun trigliserida bisa juga diperoleh dari hasil metabolisme karbohidrat yang berupa piruvat, kemudian piruvat masuk ke dalam tahap lebih lanjut untuk menghasilkan asetil-KoA, glukosa dapat menjadi prekursor utama dalam sintesis trigliserida (Goncalves et al., 2015). Hasil sintesis tersebut kemudian diangkut oleh darah dalam bentuk $\beta$-lipoprotein dan selanjutnya disimpan ke dalam kuning telur sebagai globula-globula lipid.

Kadar trigliserida lebih rendah dengan pemberian tepung bawang putih level $5 \mathrm{~g}$, 
jika dibandingkan dengan level pemberian bawang putih yang lebih tinggi. Rendahnya kadar trigliserida membuktikan bahwa pemberian bawang putih dapat menurunkan kadar trigliserida. Hal tersebut sejalan dengan hasil penelitian Peinado et al. (2013) menyatakan bahwa bawang putih mampu menurunkan aktivitas Glycerol-3-phosphate dehydrogenase (GPDH). Diketahui bahwa GDPH merupakan enzim yang perperan dalam biosintesis trigliserida.

Hasil penelitian ini menunjukan bahwa setiap pemberian tingkatan ekstrak bawang putih dapat menurunkan kadar LDL sampai level pemberian $80 \mathrm{~g}$ tepung bawang putih. Hasil penelitian ini menunjukkan bahwa pemberian ekstrak bawang putih yang tepat bagi puyuh untuk menurunkan kadar LDL masih berpotensi pada level tepung bawang putih dengan kadar lebih dari $80 \mathrm{~g} / \mathrm{kg}$ ransum. Hasil penelitian ini sejalan dengan hasil penelitian sebelumnnya bahwa performans ayam petelur meningkat setelah pemberian bawang putih sebesar 5 dan $10 \mathrm{~g} / \mathrm{kg}$ pakan (Royer et al., 2016).

Semakin banyak tingkat pemberian ekstrak bawang putih dapat mempengaruhi kadar LDL dalam darah, hal tersebut terjadi karena senyawa DADS merupakan suatu disulphide-oxyde tidak jenuh. DADS dapat menghambat kerja enzim 3-Hidroksi-3metilglutaril-KoA (HMG-KoA) reductase (Roland et al., 2016). Enzim HMG-KoA reduktase berperan sebagai katalisator dalam biosintesis kolesterol. Enzim ini berperan mengubah HMG-KoA menjadi mevalonat, yang selanjutnya akan mengalami dekarboksilasi membentuk unit isoprenoid. Unit isoprenoid akan bergabung membentuk skualen. Selanjutnya skualen akan dikonversi menjadi lanosterol dan akhirnya lanosterol akan dikonversi lagi menjadi kolesterol (Gray et al., 2015)) Penghambatan terhadap HMGKoA reduktase menyebabkan penurunan sintesa kolesterol dan meningkatkan jumlah reseptor LDL (Behera et al., 2016). Hal ini menyebabkan kadar LDL plasma menurun.

Penurunan aktivitas HMG Ko-A oleh ekstrak bawang putih mempengaruhi aktivitas reseptor LDL yang merupakan pusat metabolisme kolesterol (Mushawwir dkk., 2010; Won et.al., 2012) dan meningkatkan aktivitas apo-a yang berikatan dengan HDL. Peningkatan aktivitas apo-a yang berikatan dengan HDL menurunkan konsentrasi LDL dalam darah.

Peningkatan kadar HDL dengan pemberian ekstrak bawang putih hingga $80 \mathrm{~g}$ per kilogram ransum mengindikasikan aktifitas dari senyawa senyawa aktif dapat meningkatkan kadar HDL, salah satunya minyak atsiri. Minyak atsiri merupakan komponen yang mempengaruhi penurunan kolesterol dengan menghambat kerja enzim 3-Hidroksi-3-metilglutaril-KoA (HMGKoA) reduktase (Siskos et al., 2017; Mushawwir et al., 2018), yang berperan sebagai katalisator dalam biosintesis kolesterol (De Castro et al., 2013). Hal ini didukung dengan hasil penelitian pemberian minyak atsiri bawang putih menurunkan kadar kolesterol yang berpengaruh pula terhadap peningkatan kadar HDL (Fabris et al., 2017).

Pemberian tepung bawng putih tampak efektif menurunkan laju lipogenesis dalam keadaan cekaman panas. Hasil penelitian (Tabel 2) menunjukkan bahwa pemberian tepung bawang putih tampak menurunkan seluruh lemak, trigliserida, kolesterol dn LDL $(\mathrm{P}<0,05)$. Secara keseluruhan, efektifitas tepung bawng putih dalam menurunkan laju lipogenesis menunjukkan bahwa kandungan atsiri dan diallyl Dn-Sulfida mampu memperbaiki keseimbangan metabolisme (Ao et al., 2010; Peinado et al., 2012) terkait regulasi panas dan homeostasis (Roland et $a l ., 2016)$. Cekaman panas yang secara terus menerus dalam kondisi tinggi menyebabkan prilaku panting guna mengevaporasikan panas tubuhnya.

\section{KESIMPULAN DAN SARAN}

Berdasarkan hasil penelitian disimpulkan bahwa cekaman panas terhadap ternak puyuh mampu ditanggulangi dengan pemberian tepung bawang poutih. Kandungan yang terdapat dalam tepung bawang putih memiliki peran penting dalam 
mencegah peran lipotein dalam transportasi lipid menuju liver untuk proses vitellogenesis. Kondisi menyebabkan secara keseluruhan mampu menanggulangi perubahan metabolisme terkait stres panas.

Disarankan penggunaan tepung bawang putih dalam mencegah penurunan performans ternak yang signifikan sebagai dampak cekaman panas. Namun, perlu kajian lebih lanjut terhadap efisiensi penggunaan bahan baku garlik (bawang putih) tersebut.

\section{UCAPAN TERIMA KASIH}

Ucapan Terima Kasih disampaikan kepada pimpinan dan seluruh staf Yayasan Nurul Huda Sukabumi, telah membantu dalam menyediakan fasilitas kandang penelitian dan hewan percobaan. Penghargaan juga disampaikan kepada pihak CV. Indosain dan Laboratorium Fisologi Ternak dan Biokimia Fakultas Peternakan Universitas Padjadjaran, atas kesediaannya dalam mengakses beberapa kit analisis terkait parameter penelitian ini.

\section{DAFTAR PUSTAKA}

Al-Haidary A., D.E. Spiers, G.E. Rottinghaus, G.B. Garner, M.R. Ellersieck. 2001. Thermoregulatory ability of beef heifers following intake of endophyte-infected tall fescue during controlled heat challenge. J. of Anim. Sci. 79: 1780-1788.

Ao, X., J.S., Yoo J. H Lee., H.D. Jang, J.P. Wang, T.X. Zhou. 2010. Effects of fermented garlic powder on production performance, egg quality, blood profiles and fatty acid composition of egg yolk in laying hens. J. of Anim. Sci. 23:786-791.

Behera, N.K., L.K. Babu, S.K. Sahono, S.C. Giri, P.K. Pati, B. Panigrahi and S.K. Joshi. 2016. Effect of feeding different levels of protein on mortality, carcass characteristics, biochemical parameter, time motion study and economics of Desi Ducks under intensive system of rearing. Asian J. of Anim. Sci. 10:106112.

Chauhan, S.S., P. Celi, B. J. Leury, I. J. Clarke, F.R. Dunshea. 2014. Dietary antioxidants at supranutritional doses improve oxidative status and reduce the negative effects of heat stress in sheep. J. of Anim. Sci. 92: 3364-3374.

Choi, I.H., W.Y. Park, Y.J. Kim. 2010. Effect of dietary garlic powder and $\alpha$ tocopherol supplementation on performance, serum cholesterol levels, and meat quality of chicken. Poult. Sci. 89:1724-1731.

De Castro, N.M., P. Yaqoob, M. de la Fuente, I. Baeza, S.P. Claus. 2013. Premature impairment of methylation pathway and cardiac metabolic dysfunction in falfa obese Zucker rats. J. Proteome Res. 12:1935-45.

Fabris, T.F , J. Laporta, F.N. Corra. 2017. Effect of nutritional immunomodulation and heat stress during the dry period on subsequent performance of cows. J. Dairy Sci. 100:6733-42.

Goncalves, R. L. S., C. L. Quinlan, I. V. Perevoshchikova, M. Hey-Mogensen, and M. D. Brand. 2015. Sites of superoxide and hydrogen peroxide production by muscle mitochondria assessed ex vivo under conditions mimicking rest and exercise. J. Biol. Chem. 290:209-227.

Gray, L.R., M.R. Sultana, A.J. Rauckhorst. 2015. Hepatic mitochondrial pyruvate carrier 1 is required for efficient regulation of gluconeogenesis and whole-body glucose homeostatis. Cell Metab. 22:669-81.

Howard J.T., S.D. Kachman, M.K. Nielsen, T.L. Mader, M.L. Spangler. 2013. The effect of myostatin genotype on body temperature during extreme temperature events. J. of Anim. Sci. 91:3051-3058.

Kim Y. J., S.K. Jin, H.S. Yang. 2009. Effect of dietary garlic bulb and husk on the physicochemical properties of chicken meat. Poult. Sci. 88:398-405. 
Latipudin, D. dan A. Mushawwir. 2011. Regulasi Panas Tubuh Ayam Ras Petelur Fase Grower dan Layer. J. Sains Peternakan Indonesia. 6:77-82.

Lee D.H., S.R. Lim, S.S. Ra, J.D. Kim. 2014. Effects of dietary garlic powder on growth, feed utilization and whole body composition change in fingerling sterlet sturgeon, Acipenser ruthenus. AsianAutralas. J. of Anim. Sci. 27:14191429.

Loyau T., S. Metayer-Coustard, C. Berri, S. Crochet, E. Cailleau-Audouin, M. Sannier, P. Chartrin, C. Praud, C. Hennequet-Antier, N. Rideau, N. Courousse, Mignon-Grasteau, N. Everaert, M.J. Duclos, S. Yahav, S. Tesseraud, A. Collin. 2014. Thermal manipulation during embryogenesis has longterm effects on muscle and liver metabolism in fast-growing chickens. PLoS One 9: e105339.

Ma X., Y. Lin, H. Zhang. W. Chen, S. Wang, D. Ruan, Z. Jiang. 2014. Heat stress impairs the nutritional metabolism and reduces the productivity of egg-laying ducks. Anim. Reprod. Sci. 145:182190.

Mushawwir A. dan D. Latipuddin. 2013. Biologi Sintesis Telur, perspektif Fisologi, Biokimia dan Molekuler Produksi Telur. Penerbit Graha Ilmu, Yogyakarta.

Mushawwir, A, U.H. Tanuwiria, Kurnia Kamil, L. Adriani, R. Wiradimadja, N. Suwarno. 2018. Evaluation of Haematological Responses and Blood Biochemical Parameters of Heat-stressed Broilers with Dietary Supplementation of Javanese Ginger Powder (Curcuma xanthorrhiza) and Garlic Extract (Allium sativum). Inter. J. of Poult. Sci. 17:452-458.

Mushawwir, A. 2015. Biokimi Nutrisi. Widya Padjadjaran, Bandung.

Mushawwir, A. dan D. Latipudin. 2011. Beberapa Parameter Biokimia Darah Ayam Ras Petelur Fase Grower dan Layer dalam Lingkungan "Upper
Zonathermoneutral. J. Peternakan Indonesia. 13:191-198.

Mushawwir, A. dan D. Latipudin. 2012. Respon fisiologi thermoregulasi ayam ras petelur fase grower dan layer. Proseding seminar zootechniques for Indogeneous resources development, ISAA Fakultas Petenakan Universitas Diponegoro. Proceeding of National Seminar on Zootechniques. 1:23-27.

Mushawwir, A., L.Adriani, K.A. Kamil. 2011. Prediction Models for Olfactory Metabolic and Sows\% Rnareticulocyt (Rnart) by Measurement of Atmospheric Ammonia Exposure and Microclimate Level. J. of the Indon. Tropical Anim. Agric. 36:14-20.

Mushawwir, A., N. Suwarno. A.A. Yulianti. 2019. Profil Malondialdehyde (MDA) dan Kreatinin Itik Fase Layer yang Diberi Minyak Atsiri Garlic Dalam Kondisi Cekaman Panas. J. Ilmu dan Industri Peternakan. 5:1-11.

Mushawwir, A., Y.K. Yong, L. Adriani, E. Hernawan, K.A. Kamil. 2010. The Fluctuation Effect of Atmospheric Ammonia (NH3) Exposure and Microclimate on Hereford Bulls Hematochemical. J. of the Indon. Tropical Anim. Agric. 35:232-238.

Olobatoke, R.Y., S. D. Mulugeta. 2011. Effect of dietary garlic powder on layer performance, fecal bacterial load, and egg quality. Poult. Sci. 90:665-670.

Oresanya, T. F., A. D. Beaulieu, and J. F. Patience. 2008. Investigations of energy metabolism in weanling barrows: The interaction of dietary energy concentration and daily feed (energy) intake. J. of Anim. Sci. 86:348-363.

Pearce, S. C., N.K. Gabler, J.W. Ross, J. Escobar, J.F. Patience, R. P. Rhoads, L.H. Baumgard. 2013. The effect of heat stress and plane of nutrition on metabolism in growing pigs. Olobatoke. Anim. Sci. 91:2108-2118.

Peinado M. J., R. Ruiz, A. Echavarri. 2012. Garlic Derivative Propyl Propane Thiosulfonate Is Effective Against 
Broiler Enteropathogens In Vivo Poult. Sci. 91:2148-2157.

Roland, L, M. Drillich, D. Klein-Jobstl, M. Iwernes. 2016. Invited review: Influence of climatic conditions on the development, performance, and health of claves. J. of Dairy Sci. 99:2438-52.

Royer E.F., T. Barbé, D. Guillou, Y. Rousselière, E. Chevaux. 2016. Development of an oxidative stress model in weaned pigs highlighting plasma biomarkers' specificity to stress inducers. J. of Anim. Sci. 94:48-53.

Sadiah, I.N dan A. Mushawwir. 2015. Mortalitas embrio dan daya tetas itik lokal (Anas sp.) berdasarkan pola pengaturan temperatur mesin tetas. Fakutas Peternakan Universitas Padjadjaran.

Shinder, D., M. Rusal, J. Tanny, S. Druyan, and S. Yahav. 2007. Thermoregulatory Responses of Chicks (Gallus domesticus) to Low Ambient Temperatures at an Early Age. Poult. Sci. 86:2200-2209.
Siskos, A.P., P.W. Jain, Romisch-Margl. 2017. Interlaboratory reproducibility of a targeted metabolomics platform for analysis of human serum and plasma. Anal. Chem. 89:656-65.

Slimen, B, T. Najar, A. Ghram, M. Abdrranna. 2016. Heat stress effects on livestock: molecular, cellular and metabolic aspects, a review. J. of Anim. Physiology and Anim. Nutrition. 100:401-12.

Tao S., G.E. Dahl. 2013. Invited review: Heat stress impacts during late gestation on dry cows and their calves. J. of Dairy Sci. 96:4079-4093.

Won, S. G. L., G. Xie, R. Boddicker, J. N. Rhoades, M. C. Lucy, T. J. Safranski, J. T. Selsby, S. Lonergan, L. H. Baumgard, J. W. Ross, and R. P. Rhoads. 2012. Acute duration heat stress alters expression of cellular bioenergetic-associated genes in skeletal muscle of growing pigs. J. of Anim. Sci. 90 (E-Suppl. 3):573. 